\title{
The Economics of Fruit and Vegetable Production Irrigated with Reclaimed Water Incorporating the Hidden Costs of Life Cycle Environmental Impacts
}

\author{
Kledja Canaj ${ }^{1}$, Andi Mehmeti ${ }^{2, *}$ and Julio Berbel ${ }^{3}$ (D) \\ 1 Department of Management, Finance and Technology, LUM Giuseppe Degennaro University, \\ S.S. 100-Km 18, 70010 Casamassima, Italy; canaj.phdstudent@lum.it \\ 2 International Center for Advanced Mediterranean Agronomic Studies (CIHEAM-Bari), Via Ceglie 9, \\ Valenzano, 70010 Bari, Apulia, Italy \\ 3 Water, Environmental and Agricultural Resources Economics (WEARE) Research Group, \\ Universidad de Córdoba, 14014 Córdoba, Spain; berbel@uco.es \\ * Correspondence: mehmeti@iamb.it; Tel.: +39-0804606354
}

Citation: Canaj, K.; Mehmeti, A.; Berbel, J. The Economics of Fruit and Vegetable Production Irrigated with Reclaimed Water Incorporating the Hidden Costs of Life Cycle Environmental Impacts. Resources 2021, 10, 90. https://doi.org/ $10.3390 /$ resources 10090090

Academic Editor: Carlo Ingrao

Received: 31 July 2021

Accepted: 30 August 2021

Published: 3 September 2021

Publisher's Note: MDPI stays neutral with regard to jurisdictional claims in published maps and institutional affiliations.

Copyright: (c) 2021 by the authors. Licensee MDPI, Basel, Switzerland. This article is an open access article distributed under the terms and conditions of the Creative Commons Attribution (CC BY) license (https:/ / creativecommons.org/licenses/by/ $4.0 /)$.

\begin{abstract}
The estimation and quantification of external environmental costs (hidden costs) are crucial to sustainability assessments of treated wastewater reuse projects. These costs, however, are rarely considered in economic analysis studies. In this work, monetized life cycle assessment (LCA) and life cycle costing (LCC) were combined into a hybrid model to calculate cradle-to-farm gate external environmental costs (EEC) and internal costs (IC) of producing $1 \mathrm{t}$ of plant-based product irrigated with reclaimed water in a Mediterranean context. The total cost was calculated by combining monetized LCA and LCC results. The results for the crops under consideration were $119.4 € / \mathrm{t}$ for tomatoes, $344.4 € / \mathrm{t}$ for table grapes, and $557 € / \mathrm{t}$ for artichokes. Our findings show that there are significant hidden costs at the farm level, with EEC accounting for $57 \%, 23 \%$, and $38 \%$ of the total cost of tomatoes, table grapes, and artichokes, respectively. Electricity use for water treatment and fertilization generated most of the EEC driven by the global warming, particulate matter, acidification, and fossil resource scarcity impact categories. When compared to groundwater, the higher internal costs of reclaimed water were offset by lower external costs, particularly when supported by low-energy wastewater treatment. This demonstrates that incorporating EEC into economic analyses might generate a better understanding of the profitability of treated wastewater reuse in crop production. In Italy and the Mediterranean region, research on the sustainability of water reuse in irrigation through life cycle thinking is still limited. Using a multi-metric approach, our analysis brought new insights into both economic and environmental performance - and their tradeoff relationships in wastewater reuse for irrigation of agricultural crops. In future research, it would be of interest to use different monetization methods as well as to investigate social externalities to explore their size and role in the total external costs.
\end{abstract}

Keywords: life cycle assessment (LCA); total cost; monetization; cost accounting; agricultural irrigation; reclaimed wastewater; water reuse

\section{Introduction}

Irrigated agriculture in the Mediterranean is under considerable pressure to produce more with less water [1]. Over the years, conventional groundwater and surface water resources have been over-extracted, resulting in a multi-faceted crisis with ecological, economic, and social dimensions. In this context, a mix of supply-enhancing and demandmanaging options becomes essential for the economic viability of farming systems. On the supply side, the European Commission has advocated the use of reclaimed water for agricultural irrigation (water reuse) as a relevant solution to address water scarcity [2] and has recently approved regulation 2020/741 [3] to harmonize and improve water reuse in the European Union. 
It has been argued that the safe use of reclaimed water in irrigated agriculture provides numerous environmental and socio-economic benefits [4]. On the contrary, the debate over the significant reclamation and health costs has prompted the need for a holistic assessment of the sustainability impacts of the technological chain for water reclamation and reuse. Economic and environmental impacts are evaluated by using both life cycle costing (LCC) and life cycle assessment (LCA) methodologies. Life cycle costing (LCC) is well developed $[2,5]$ in terms of the real financial burdens (direct monetary costs) for the construction and operation of treatment plants. On the other hand, LCA studies of agricultural products irrigated with treated wastewater have been developed, focusing on physical (or "environmental") aspects [6-9]. Other studies [9] report LCC by describing the economic burden of the product life cycle, alongside its environmental impacts. Recently, Canaj et al. [10] provided a quantitative assessment of the environmental impacts, costs, and eco-efficiency of crop production with reclaimed water.

The external environmental costs (hidden costs) are enormously important for feasibility studies of wastewater collection, treatment, and reuse projects [11]. External costs are unaccounted and uncompensated impacts (for one or more stakeholders) that are not reflected in the prices of the goods and services provided [12]. These costs affect third parties and are borne by various actors in the supply chain. They are classified as environmental costs if they have a direct impact on the environment, or social costs if they have a direct impact on people's well-being [13]. While internal impacts can be easily converted into monetary units, external effects (or externalities) are not taken into account by the market and must be quantified using economic valuation methods [11].

External cost analysis via monetization is gaining momentum in the development of business models and more sustainable practices [14]. Monetization is the conversion of environmental impacts caused by the release of environmentally harmful substances or the use of natural resources to monetary units [15]. Monetizing LCA results is one form of expressing environmental impacts in terms of costs [16]. The advantage of monetized environmental impacts is that they can overcome the problem of trade-offs between the many impact categories that an LCA normally analyzes [15]. Furthermore, the concept extends beyond the economic dimension of sustainability [17].

A growing number of researchers are estimating the environmental external costs of products and services by the monetary valuation of LCA results. Hamedani et al. [18] applied monetized LCA to weigh the environmental benefits against the environmental costs of biochar production from willow versus biochar production from pig manure. Olba-Zięty et al. [19] used the ReCiPe midpoint method [20] to calculate the cradle-tofarm environmental external cost of poplar wood chips in Poland. Similarly, Al-Qahtani et al. [21] used a monetization analysis based on ReCiPe 2016 [20] to calculate the true costs of different hydrogen production routes. In Israel, Greenfeld et al. [22] used environmental pricing [12] to monetize the environmental impacts of integrated aquaponic farming compared to separate systems. Huysegoms et al. [23] combined the ReCiPe endpoint with monetization approaches (Stepwise 2006 and Ecovalue 08) to express the environmental impact of the remediation project in a monetary value. Theregowda et al. [24] calculated the environmental impact costs of air emissions from the tertiary treatment of municipal wastewater for reuse in cooling systems. The True Price Foundation [25] has developed case studies to quantify and monetize the external costs (both social and environmental impacts) of bananas, apples, milk, bread, palm oil, and other agri-food products. To date, few studies $[11,16,26,27]$ have analyzed the external economic impacts of water reuse projects without considering an integrated life cycle perspective and all crop growing processes on arable land. It is obvious that the external cost analysis of wastewater reuse in crop production via LCA is still at an early stage and more case studies are needed to advance the research field. Bringing site-based "hidden" environmental costs will broadening the perspective to identify options with the greatest combined economic and environmental leverage. Moreover, stakeholders' demand for life cycle-based information and sustainably produced agricultural products is increasing [28]. 
A monetized LCA was used in this study, along with life cycle costing, to calculate the external environmental costs (EEC) and internal costs (IC) of crop cultivation irrigated with treated municipal wastewater. The total cost was calculated by combining monetized LCA and LCC results. Another goal was to compare the performance of crop systems irrigated with reclaimed water and the reference situation where conventional groundwater was used as a source of irrigation. The crops selected for the study were tomatoes, table grapes, and artichokes growing in the Apulia region, Southern Italy. This assessment was used to answer two research questions:

RQ1. What are the external and total costs of crop cultivation irrigated with reclaimed water?

RQ2. How does the source of water (reclaimed vs. groundwater) affect the cost performance?

This research makes useful practical and methodological contributions. First, it is one of the few studies in the Italian and Mediterranean contexts to conduct a full-fledged LCA to calculate the external environmental costs of crop production with reclaimed water. Second, it enables the capitalization of knowledge about the financial (economic) and non-financial (environmental) impacts of crop cultivation with treated wastewater via a final composite economic-environmental indicator expressed in economic terms. Third, it provides an outlook on the practical applicability of external environmental costs as an input to the economic feasibility analysis of crop production using various water sources.

\section{Materials and Methods}

\subsection{Assessment Framework}

The assessment framework was divided into four basic steps (Figure 1):

(1) Make an inventory of relevant crop input-output data and convert it to actual environmental indicators through the LCA approach.

(2) Apply economic weighting of LCA results and express results in economic terms as external environmental costs (EEC).

(3) Calculate the internal cost (IC) through a simplified life cycle costing analysis.

(4) Combine EEC with IC to produce a final synthetic economic-environmental indicator expressed in monetary terms, referred to as total cost.

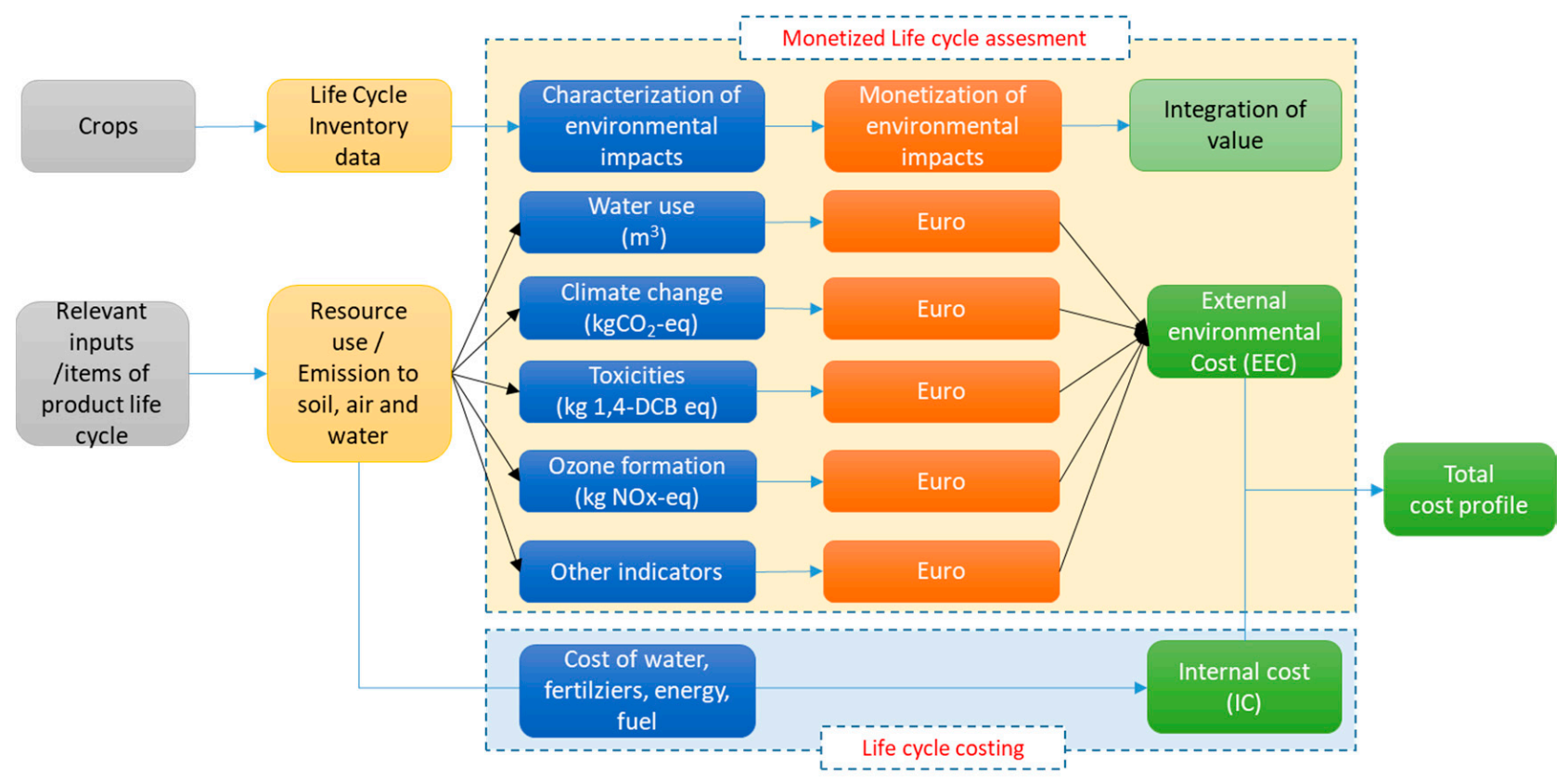

Figure 1. The assessment framework combining external environmental costs and internal costs. 


\subsubsection{Modeling External Environmental Cost Via LCA}

In this study, we modeled the EEC from the cradle-to-farm gate perspective (Figure 2). This means that all process inputs and outputs were considered up to the farm exit gate. The assessment included all crop growing processes on arable lands, such as fertilization, irrigation with treated wastewater (including construction, operation, and demolition stages of the targeted tertiary systems), and the consumption of fuel for operations, plant protection, and transport. The direct air, soil, and water emissions on the field were also taken into account. The temporal and geographical scope was set from 2010 to 2020 in Southern Italy. The assessment follows an attributional LCA (ALCA) modelling the environmental impacts generated by the production of one ton at the farm gate. A consistent environmental cut-off was applied based on the LCA inventory to standard production practices. This means that only costs directly related to LCA inventory items are considered (e.g., raw materials, fertilizers, water, energy).

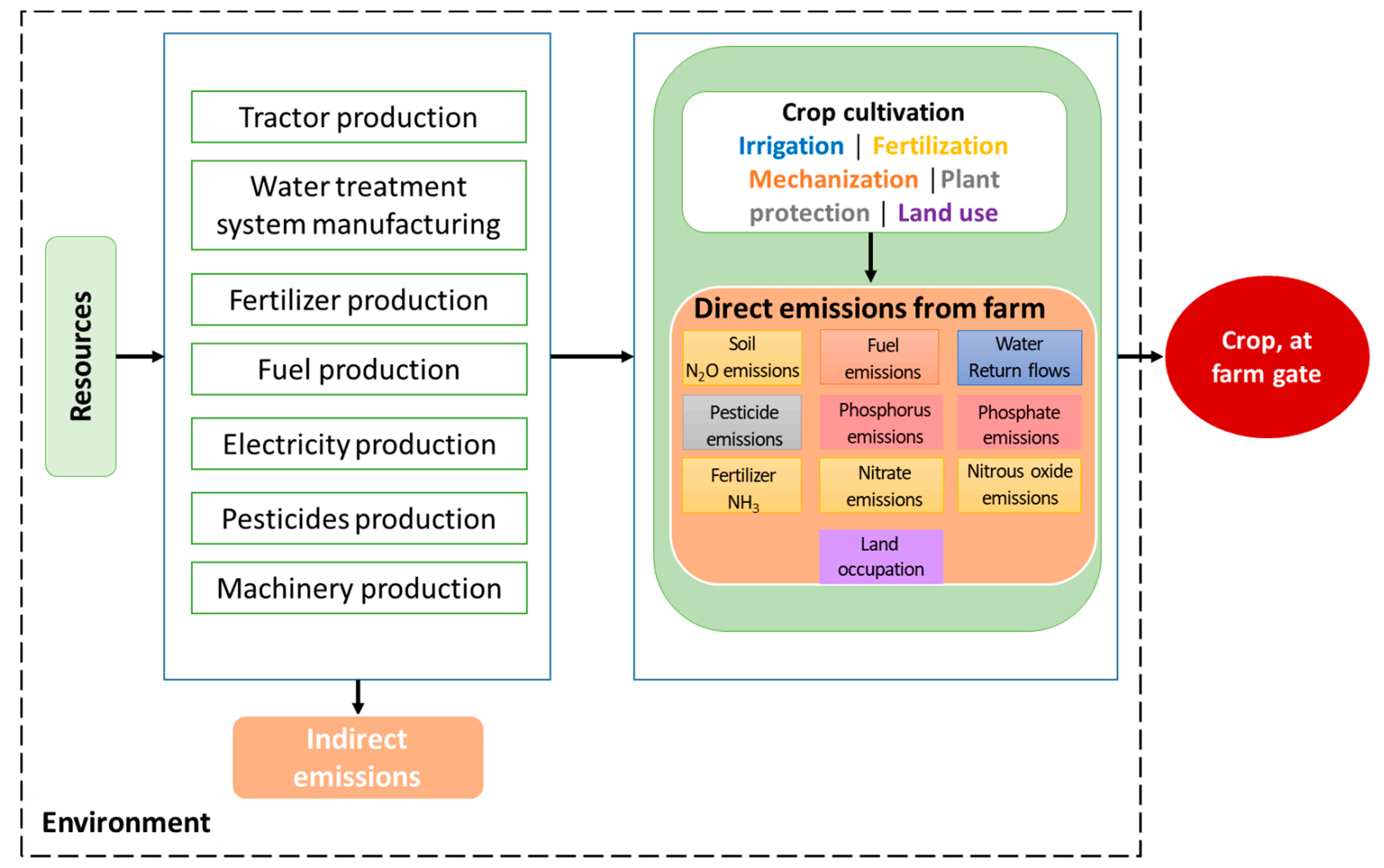

Figure 2. System boundary and associated processes included in the calculation of external environmental costs.

\subsubsection{Inventory Data}

Table 1 summarizes the main primary data on inputs used to cultivate the soil surface for each crop. While emissions were calculated using specific models, information on production practices was gathered through literature surveys (tomatoes and artichokes) and experimental sites (table grapes). These data were validated by experienced agronomists and agricultural scientists. The key inventory data for tomato cropping systems were retrieved from Vergine et al. [29]. The full-scale tertiary treatment was composed of sand filtration, membrane ultrafiltration, and UV radiation with an overall energy requirement of $1.68 \mathrm{kWh} / \mathrm{m}^{3}$. Energy consumption was made up of $51 \%$ filtration (sand filter plus membranes), 34\% sand filter backwashing, $8 \%$ membranes backwashing and chemical cleaning, and $8 \%$ ultraviolet (UV) radiation. Fertilization was composed of $200 \mathrm{~kg} \mathrm{~N} / \mathrm{ha}$ (ammonium nitrate), $250 \mathrm{~kg} \mathrm{P} /$ ha (triple superphosphate), and $150 \mathrm{~kg} \mathrm{~K} / \mathrm{ha}$ (potassium sulfate). The average gross irrigation requirement was $5000 \mathrm{~m}^{3} /$ ha. 
Table 1. Input and output inventory data for crops under study.

\begin{tabular}{|c|c|c|c|c|}
\hline Parameter & Unit & Tomatoes & Table Grapes & Artichokes \\
\hline Location & - & Trinitapoli & Acquaviva delle Fonti & Trinitapoli \\
\hline Treatment system & $\mathrm{m}^{3} / \mathrm{h}$ & 12 & 280 & 300 \\
\hline Type of system & - & $\begin{array}{c}\text { Ultrafiltration + UV } \\
\text { disinfection } \\
\text { Input }\end{array}$ & $\begin{array}{l}\text { Disk filtration + UV } \\
\text { disinfection }\end{array}$ & $\begin{array}{c}\text { Ultrafiltration + UV } \\
\text { disinfection }\end{array}$ \\
\hline Irrigation water & $\mathrm{m}^{3} / \mathrm{ha}$ & 5000 & 3160 & 3300 \\
\hline Electricity & $\mathrm{kWh} / \mathrm{ha}$ & 8400 & 2085.6 & 1760 \\
\hline N-based fertilizers & $\mathrm{kg} / \mathrm{ha}$ & 200 & 131.5 & 180 \\
\hline P-based fertilizers & $\mathrm{kg} / \mathrm{ha}$ & 250 & 70 & 70 \\
\hline K-based fertilizers & $\mathrm{kg} / \mathrm{ha}$ & 100 & 70 & 80 \\
\hline Diesel fuel & $\mathrm{kg} / \mathrm{ha}$ & 572 & 205 & 323 \\
\hline Machine time & $\mathrm{h} / \mathrm{ha}$ & 170 & 30 & 76 \\
\hline Pesticide & $\mathrm{kg} / \mathrm{ha}$ & - & 12.4 & 17 \\
\hline \multicolumn{5}{|c|}{ Farm Output } \\
\hline Crop Yield with reclaimed water & ton/ha & 80 & 21 & 8.5 \\
\hline Ammonia & $\mathrm{kg} / \mathrm{ha}$ & 24.28 & 15.96 & 21.85 \\
\hline Dinitrogen monoxide & $\mathrm{kg} / \mathrm{ha}$ & 4.16 & 2.74 & 3.75 \\
\hline Nitrogen oxides & $\mathrm{kg} / \mathrm{ha}$ & 0.66 & 0.43 & 0.59 \\
\hline Nitrates & $\mathrm{kg} / \mathrm{ha}$ & 263.75 & 173.41 & 237.37 \\
\hline Ammonia & $\mathrm{kg} / \mathrm{ha}$ & 0.01202 & 0.00431 & 0.00679 \\
\hline Benzo(a)pyrene & $\mathrm{kg} / \mathrm{ha}$ & $1.66 \times 10^{-5}$ & $6.47 \times 10^{-6}$ & $1.02 \times 10^{-5}$ \\
\hline Cadmium & $\mathrm{kg} / \mathrm{ha}$ & $6.02 \times 10^{-6}$ & $2.16 \times 10^{-6}$ & $3.14 \times 10^{-6}$ \\
\hline Carbon dioxide, fossil & $\mathrm{kg} / \mathrm{ha}$ & 1879.0 & 673.4 & 1061.1 \\
\hline Carbon monoxide, fossil & $\mathrm{kg} / \mathrm{ha}$ & 6.85 & 2.45 & 3.87 \\
\hline Chromium & $\mathrm{kg} / \mathrm{ha}$ & $3.01 \times 10^{-5}$ & $1.08 \times 10^{-5}$ & $1.7 \times 10^{-5}$ \\
\hline Copper & $\mathrm{kg} / \mathrm{ha}$ & 0.00102 & 0.00037 & 0.00058 \\
\hline Dinitrogen monoxide & $\mathrm{kg} / \mathrm{ha}$ & 0.0721 & 0.0258 & 0.0407 \\
\hline Tetrachlorodibenzo-p-dioxin & $\mathrm{kg} / \mathrm{ha}$ & $3.64 \times 10^{-11}$ & $1.29 \times 10^{-11}$ & $2.03 \times 10^{-11}$ \\
\hline Methane, fossil & $\mathrm{kg} / \mathrm{ha}$ & 0.097 & 0.035 & 0.055 \\
\hline Nickel & $\mathrm{kg} / \mathrm{ha}$ & $4.22 \times 10^{-5}$ & $1.51 \times 10^{-5}$ & $2.38 \times 10^{-5}$ \\
\hline Nitrogen oxides & $\mathrm{kg} / \mathrm{ha}$ & 265.1 & 95.0 & 149.7 \\
\hline NMVOC & $\mathrm{kg} / \mathrm{ha}$ & 3.11 & 1.11 & 1.76 \\
\hline $\begin{array}{l}\text { PAH, polycyclic aromatic } \\
\text { hydrocarbons }\end{array}$ & $\mathrm{kg} / \mathrm{ha}$ & 0.0020 & 0.0007 & 0.0011 \\
\hline Particulates, $<2.5 \mathrm{um}$ & $\mathrm{kg} / \mathrm{ha}$ & 2.43 & 0.87 & 1.37 \\
\hline Particulates, $>10$ um & $\mathrm{kg} / \mathrm{ha}$ & 0.162 & 0.058 & 0.091 \\
\hline Particulates, $>2.5 \mathrm{um}$, and $<10 \mathrm{um}$ & $\mathrm{kg} / \mathrm{ha}$ & 0.108 & 0.039 & 0.061 \\
\hline Selenium & $\mathrm{kg} / \mathrm{ha}$ & $6.02 \times 10^{-6}$ & $2.16 \times 10^{-6}$ & $3.4 \times 10^{-6}$ \\
\hline Sulfur dioxide & $\mathrm{kg} / \mathrm{ha}$ & 0.61 & 0.22 & 0.34 \\
\hline Zinc & $\mathrm{kg} / \mathrm{ha}$ & $6.02 \times 10^{-4}$ & $2.16 \times 10^{-4}$ & $3.4 \times 10^{-4}$ \\
\hline
\end{tabular}

The key inventory data for table grape production [10] was retrieved from the Cooperative Society of Agricultural Producers "La Molignana" in Acquaviva delle Fonti $\left(40^{\circ} 55^{\prime} 37.1^{\prime \prime} \mathrm{N} ; 16^{\circ} 50^{\prime} 47.8^{\prime \prime} \mathrm{E}\right)$. The full-scale tertiary treatment was based on surface filtration (disk filters) and UV disinfection to treat an equalized average flow rate of $6720 \mathrm{~m}^{3} /$ day, equal to about $280 \mathrm{~m}^{3} / \mathrm{h}$. The reclaimed water was applied to the crops through drip irrigation. TWW had an overall energy requirement of $33 \mathrm{~kW}$ or $0.66 \mathrm{kWh} / \mathrm{m}^{3}$. The $\mathrm{N}$-fertilizer was composed of biovegetal ( $3500 \mathrm{~kg}$ with $2 \% \mathrm{~N})$, ammonium sulfate ( $150 \mathrm{~kg}$ with $27 \% \mathrm{~N})$, and calcium nitrate $(200 \mathrm{~kg}$ with $15 \% \mathrm{~N})$. Macronutrient requirements were $131.5 \mathrm{~kg} \mathrm{~N} / \mathrm{ha}$, $70 \mathrm{~kg} \mathrm{P}_{2} \mathrm{O}_{5} / \mathrm{ha}$, and $70 \mathrm{~kg} \mathrm{~K}{ }_{2} \mathrm{O} / \mathrm{ha}$.

The key inventory data for artichoke production was retrieved from experimental work in Trinitapoli $[30,31]$. The full-scale tertiary treatment [16] was based on five sand filters (anthracite $1150 \mathrm{~kg}$, quartz sand $4500 \mathrm{~kg}$, and gravel support $2040 \mathrm{~kg}$ ), eighty-four ultrafiltration modules with triacetate hollow fiber membranes, a reinforced concrete tank $\left(180 \mathrm{~m}^{3}\right)$, two horizontal pumps AISI $316(2 \times 11 \mathrm{~kW})$, and an air compressor $(5.1 \mathrm{~kW})$. The 
electricity input for the UF unit was $66 \mathrm{~kW}$. A dose of $100 \mathrm{mg}$ sodium hypochlorite $(\mathrm{NaClO})$ was added for each $\mathrm{m}^{3}$ of water.

The emission factors for all the operations in the background system were taken from Ecoinvent 3.1 [32]. The same database was used for the field combustion emissions. The emissions to air of ammonia $\left(\mathrm{NH}_{3}\right)$, nitrous oxide $\left(\mathrm{N}_{2} \mathrm{O}\right)$, and nitrogen oxide $(\mathrm{NOx})$ were calculated following the IPCC method [33]. The emissions to surface water and groundwater of phosphorus $\left(\mathrm{P}, \mathrm{PO}_{4}{ }^{3-}\right)$ were calculated using the SALCA-P model [34].

\subsection{Cost Valuation}

There are numerous methods for weighting LCA results (at both the midpoint and endpoint levels). A review was presented by Arendt et al. [15]. The LCA indicators were assessed through ReCiPe 2016 and then monetized using LCA-based conversion factors of $72,000 € /$ DALY and $11.5 \times 10^{6} € /$ species provided by Ponsioen et al. [35] and previously used by Canaj et al. [16]. Weighting factors for each impact category are presented in Table 2. To calculate the external cost for each impact category (y), Equation (1) was used. The EEC per functional unit is the sum of all indicator costs.

$$
\text { External cost }(\mathrm{y})=\frac{\text { Environmental impact }(\mathrm{y})}{\text { Functional unit }} \times \text { Monetization factor }(\mathrm{y})
$$

Table 2. Environmental effect categories, units, and monetization factors according to ReCiPe 2016 [16].

\begin{tabular}{|c|c|c|}
\hline Impact Categories & Unit & Monetization Factors \\
\hline Fine particulate matter formation & kg PM2.5-eq & 14.00 \\
\hline Fossil resource scarcity & $\mathrm{kg}$ oil eq & 0.39 \\
\hline Freshwater ecotoxicity & $\operatorname{kg} 1,4-\mathrm{DCB}$ eq & 0.008 \\
\hline Freshwater eutrophication & $\mathrm{kg} P$ eq & 2.00 \\
\hline Global warming & $\mathrm{kgCO}_{2}-\mathrm{eq}$ & 0.15 \\
\hline Human carcinogenic toxicity & $\mathrm{kg} 1,4-\mathrm{DCB}$ eq & 0.24 \\
\hline Human non-carcinogenic toxicity & $\operatorname{kg} 1,4-\mathrm{DCB}$ eq & 0.016 \\
\hline Ionizing radiation & kBq Co-60-eq & 0.00061 \\
\hline Land use & $\mathrm{m}^{2} \mathrm{a}$ crop eq & 0.10 \\
\hline Marine ecotoxicity & $\mathrm{kg} \mathrm{1,4-DCB} \mathrm{eq}$ & 0.0012 \\
\hline Marine eutrophication & $\mathrm{kg} \mathrm{N}$ eq & 3.10 \\
\hline Mineral resource scarcity & $\mathrm{kg} \mathrm{Cu} \mathrm{eq}$ & 0.20 \\
\hline Ozone formation, Human health & $\mathrm{kg} \mathrm{NOx-eq}$ & 0.066 \\
\hline $\begin{array}{l}\text { Ozone formation, Terrestrial } \\
\text { ecosystems }\end{array}$ & kg NOx-eq & 0.0093 \\
\hline Stratospheric ozone depletion & kg CFC11-eq & 38.00 \\
\hline Terrestrial acidification & $\mathrm{kg} \mathrm{SO}_{2}$-eq. & 2.73 \\
\hline Terrestrial ecotoxicity & $\operatorname{kg} 1,4-\mathrm{DCB}$ eq & 0.00013 \\
\hline Water consumption & $\mathrm{m}^{3}$ & 0.045 \\
\hline
\end{tabular}

Internal costs (cost-purchased physical inputs or production cost) were compiled based on data presented in Table 3. Internal cost analysis follows the same functional unit and the same system boundaries to input flows identified in LCA.

The calculations were carried out using OpenLCA 1.10.3 software [36].

\section{Results}

\subsection{What Is the Size of External Environmental Costs of Crops Irrigated with Reclaimed Water?}

Figure 3 presents the cradle-to-farm gate EECs of crops irrigated with reclaimed water in the Apulia region (Southern Italy). The total EEC of $1 \mathrm{t}$ of the crop at the farm gate was estimated at $67.7 € / \mathrm{t}$ for tomatoes, $80.1 € / \mathrm{t}$ for table grapes, and $212.8 € / \mathrm{t}$ for artichokes. The difference between crops was mainly due to crop yield. The analysis confirms that a high-yielding system has a lower impact per unit of the product obtained because it requires less land to produce a given amount of food [37]. 
Table 3. Input costs for internal cost analysis.

\begin{tabular}{ccccc}
\hline Parameter & Unit & Tomatoes & Table Grapes & Artichokes \\
\hline Reclaimed water & $€ / \mathrm{m}^{3}$ & 0.24 & 0.53 & 0.42 \\
Groundwater & $€ / \mathrm{m}^{3}$ & 0.1 & 0.62 & 0.37 \\
Electricity & $€ / \mathrm{kWh}$ & 0.12 & 0.12 & 0.12 \\
Nitrogen fertilizers & $€ / \mathrm{kg}$ & 1.60 & 0.33 & 0.33 \\
P-based fertilizers & $€ / \mathrm{kg}$ & 0.96 & 0.25 & 0.25 \\
K-based fertilizers & $€ / \mathrm{kg}$ & 2.40 & 0.55 & 0.55 \\
Diesel fuel & $€ / \mathrm{kg}$ & 1 & 1 & 1 \\
Machine & $€ / \mathrm{h}$ & 25 & 25 & 25 \\
Pesticide & $€ / \mathrm{kg}$ & - & 12.40 & 17.00 \\
\hline
\end{tabular}
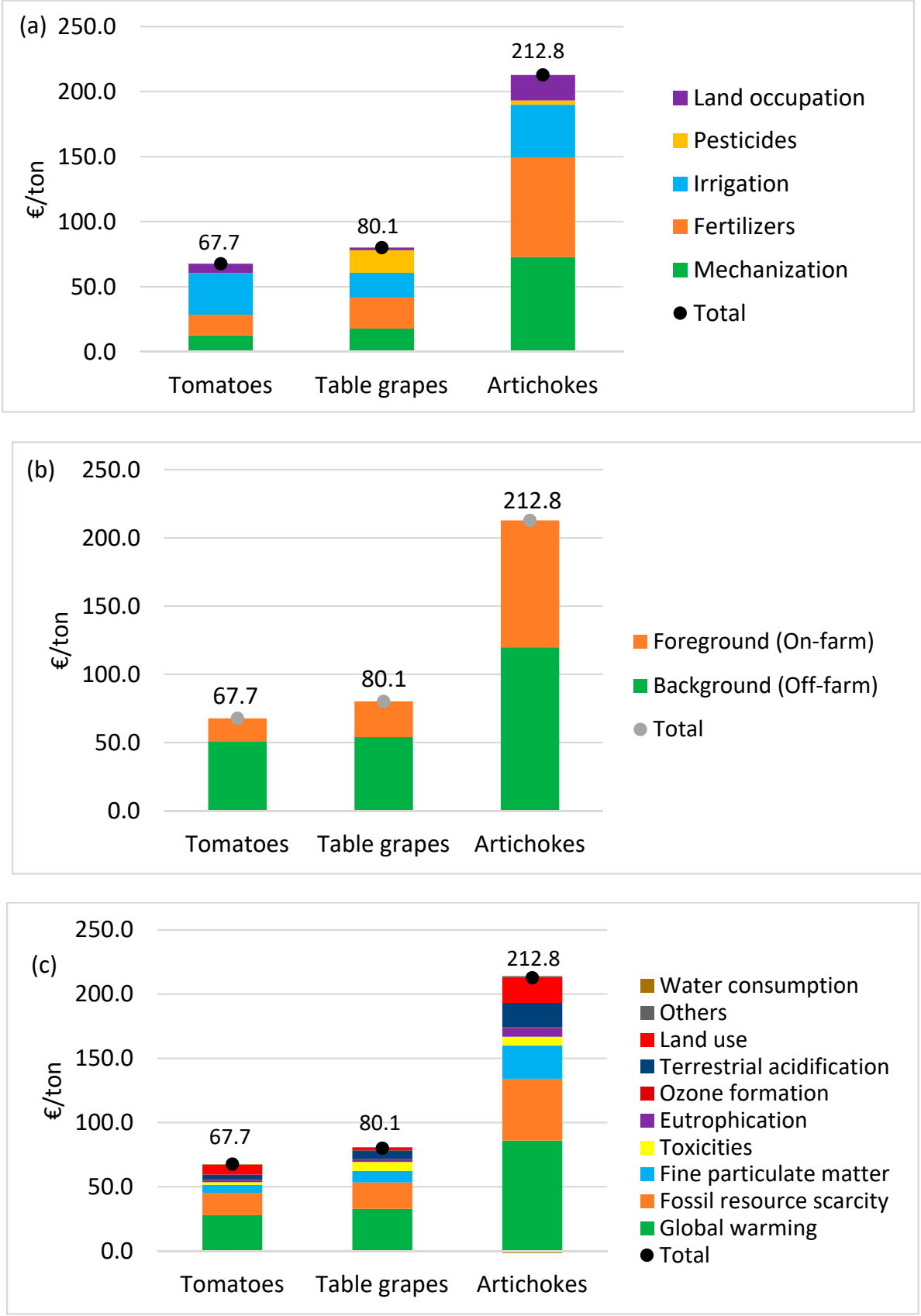

Figure 3. The external environmental cost of crops irrigated with reclaimed water in the Apulia region (Southern Italy) at the unit process (a) subsystem, and (b) indicator (c) levels following a cradle-to-gate perspective. 
Looking at the process impacts (Figure 3a), irrigation and fertilizers are the primary causes, followed by fieldwork operations and land occupation. This confirms the findings of previous studies on open-field tomatoes [38], table grapes [39], and artichokes [40], which identified irrigation and fertilization as the main environmental burdens. Irrigation as a process accounted for $46 \%$ of EEC for tomatoes, $24 \%$ for grapes, and $20 \%$ for artichokes. The irrigation cost depends on the water input and the technology used for water treatment and distribution. As a result, the irrigation EECs are much higher for water-intensive crops, reflecting the higher electricity demand for water treatment and distribution. The size of the water treatment system also influences the magnitude of EEC. The analysis of the impacts at the foreground (on-farm) and background (off-farm) levels reveals that EEC is largely caused by the increased use of background processes (Figure 3b), i.e., the production of raw materials, electricity, and infrastructure. Background processes account for $75 \%, 67 \%$, and $56 \%$ of the EEC of tomatoes, table grapes, and artichokes, respectively. Figure $3 \mathrm{c}$ depicts the results by impact category. Global warming, fossil resource scarcity, particulate matter formation, and terrestrial acidification were identified as the main causes of EECs. Because tomatoes are an annual crop, about $11 \%$ is attributed to land use. Since table grapes and artichokes are perennial crops, the land use contribution is much lower. Land occupation takes into account the effects of land use, the amount of area involved, and the duration of its occupation (changes in quality multiplied by the area and duration). Other environmental cost categories contribute relatively little to the external costs of crop production. Irrigation has the greatest impact on fossil fuel scarcity, with indirect emissions associated with the Italian electricity mix (Figure 4). In terms of particulate matter and global warming, a large part of the impact is related to mechanization $\left(\mathrm{CO}_{2}\right.$ emissions from tractors) and chemical fertilizers $\left(\mathrm{N}_{2} \mathrm{O}\right.$ and $\mathrm{NH}_{3}$ emissions into the air from fertilizer production and application). Irrigation has a significantly larger impact on the GWP and PMPF of tomatoes due to their higher water and energy consumption. Acidification impacts are the results of fertilizer use and associated on-field emissions $\left(\mathrm{NH}_{3}\right.$ and NOx).

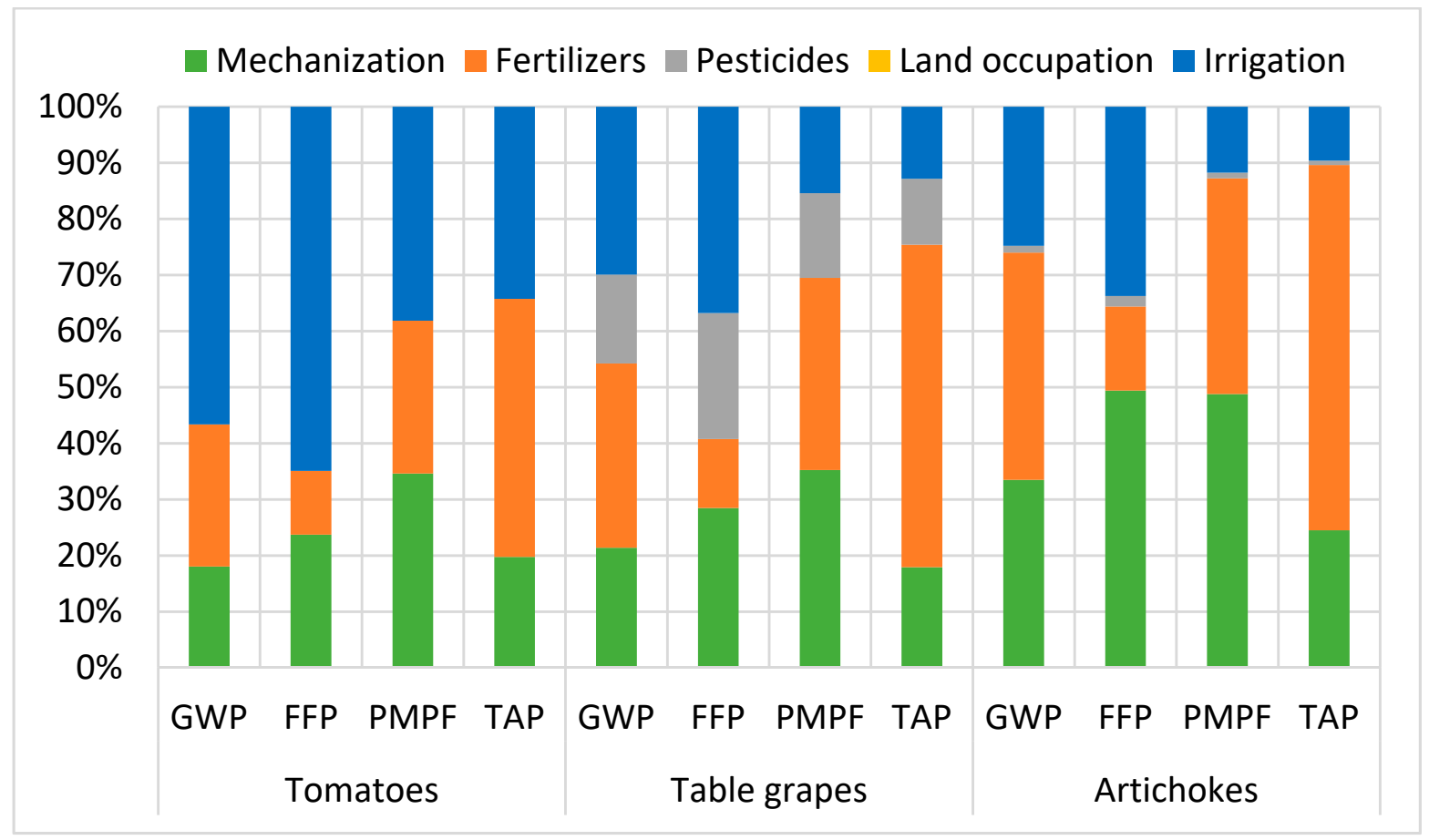

Figure 4. Process contribution on the external environmental cost of global warming (GWP), fossil fuel scarcity (FFP), particulate matter formation (PMPF), and terrestrial acidification (TAP) impact categories. 


\subsection{What Is the Total Cost of Crop Production with Reclaimed Water? The Role of Externalities}

Figure 5 depicts the total cost per crop at the farm gate, which includes both internal and external environmental costs per $1 \mathrm{t}$ of product. The total cost of producing one ton of crop was $€ 119.4$ for tomatoes, $€ 344.4$ for table grapes, and $€ 557$ for artichokes. Our analysis shows that hidden costs associated with TWW-irrigated crops are significant, accounting for $57 \%, 23 \%$, and $38 \%$ of the total cost of tomatoes, table grapes, and artichokes, respectively. This means that, for tomatoes, the environmental costs are larger than the internal costs. Irrigation costs themselves accounted for $50 \%, 35 \%$, and $38 \%$ of the total cost of tomatoes, table grapes, and artichokes, respectively.

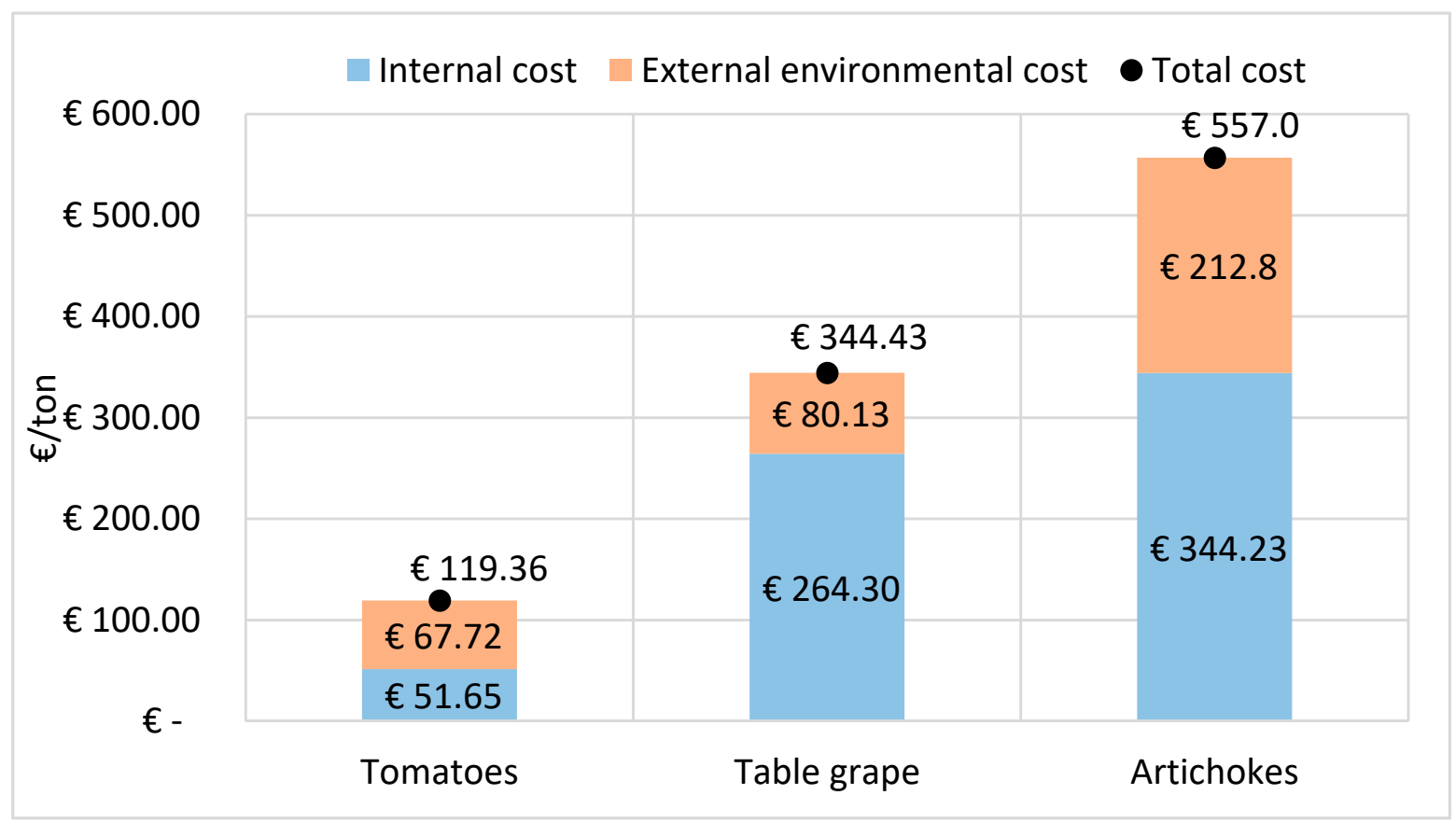

Figure 5. The total monetized cost (sum of the internal and external environmental costs) of crops irrigated with reclaimed water in the Apulia region (Southern Italy).

\subsection{How Does the Performance of Crop Cultivation Irrigated with Reclaimed Water Compare to Irrigation with Groundwater?}

We further compared the cost of crop systems irrigated with groundwater (GW) and reclaimed water (RW) to identify which sub-system had the most impact (Figure 6). Crop yield and energy input differences were modeled. The annual crop yield of crops with groundwater was considered as $85.7 \mathrm{t} / \mathrm{ha}, 23.1 \mathrm{t} / \mathrm{ha}$, and $7.2 \mathrm{t} / \mathrm{ha}$ for tomatoes, table grapes, and artichokes, respectively. The energy for irrigation was $0.34 \mathrm{kWh} / \mathrm{m}^{3}$ for tomatoes, $1.48 \mathrm{kWh} / \mathrm{m}^{3}$ for table grapes, and $0.247 \mathrm{kWh} / \mathrm{m}^{3}$ for artichokes. Water release was modeled as reaching either the ocean (groundwater) or agricultural soil (treated water). The water withdrawals from, or release to and from, natural resources was also considered.

Different studies performing comparative analyses of irrigation sources suggest that the benefits of RW are both crop- and site-specific. Moretti et al. [41] found that the use of treated wastewater for orchards achieved better outcomes for eutrophication-related environmental burdens, while it performed worse for climate change, toxicity (humans requiring freshwater), acidification, and water use. Romeiko [7] found that replacing groundwater with reclaimed water as the irrigation source significantly increased the life cycle of non-cancer impacts of corn, soybean, and wheat systems in China, but decreased the life cycle of global warming, acidification, ozone depletion, smog formation, and respiratory impacts. Azeb et al. [6] showed that irrigating cucumbers with reclaimed water has quite a similar impact to groundwater for ionizing radiation, freshwater eutrophication, 
marine ecotoxicity, land occupation, and mineral resource scarcity. Furthermore, as many case studies by Hernandez-Sanchez et al. [11] demonstrate, wastewater can be economically feasible, with the benefits outweighing the costs. Our findings show that RW irrigation can be just as profitable as, if not more profitable than, groundwater irrigation. This is because, in an economic feasibility study, RW could compensate for a higher IC with a lower EEC. This confirms the added value of monetary valuations of environmental impacts as an additional input in the economic feasibility analysis.

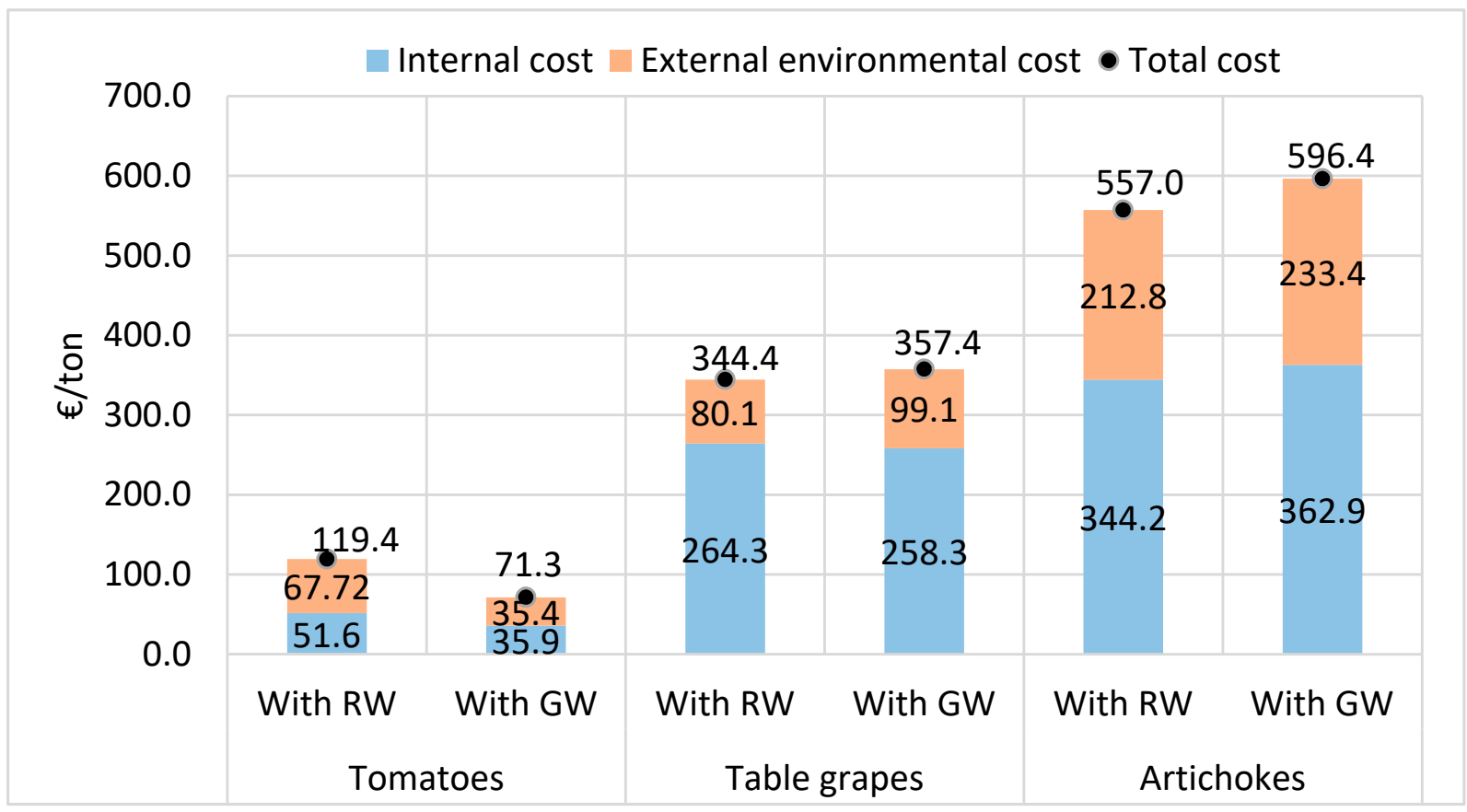

Figure 6. The total (internal + external) monetized cost of crops irrigated with reclaimed water (RW) and groundwater (GW) in the Apulia region (Southern Italy).

As presented in Figure 6, using reclaimed water as an irrigation source reduces EECs and total costs for table grapes and artichokes while increasing them for tomatoes. Overall, our model shows that crop yield, energy expenditures, characteristics of the water source, and irrigation volumes all influence performance. Most environmental impact categories are reduced by RW, especially in well-optimized systems, i.e., when using less energy for adequate wastewater treatment and management compared to pumping deep groundwater. In the case of tomatoes, water treatment necessitates significantly more energy than conventional groundwater, resulting in higher electricity costs. Costeffectiveness is also affected by the relatively small size of the water reclamation plant. In the case of artichokes, the advantages of a higher yield with RW outweigh the costs of energy and infrastructure for water reclamation. Furthermore, treatment costs are comparable to groundwater costs. In the case of table grapes, the energy required for water tertiary treatment and distribution is minor compared to the groundwater abstraction from deep wells $(>300 \mathrm{~m})$. As a result, water reuse can help to reduce direct water and energy costs as well as the external costs of environmental impacts. This assessment considered water reclamation costs as borne by farmers. This is the case of only groundwater irrigation, where all costs are private and borne by the farmers themselves. According to the current local law, the burden of the investment cost for water reuse (tertiary treatment) is not charged to farmers, but to all customers in the region [42]. Depending on the local situation, another added value would be economizing fertilizer usage from the use of nutrient-loaded waters. Considering these aspects can generate further positive results for water reuse. 


\section{Conclusions}

Economics remains one of the major barriers to the actual development of water reuse projects. In this context, cost accounting incorporating hidden costs has become an important issue in economic feasibility analyses. Combining life cycle costing with a monetized life cycle assessment, this study quantified the internal and external environmental costs of tomato, table grape, and artichoke cultivation with reclaimed water. The study investigated the magnitude of external costs and their impact on total cost performance. Monetary valuation of LCA impacts is an evolving field and there are still a lot of uncertainties regarding the quantification of external costs. Therefore, the contribution of this study is mainly methodological rather than numerical. Our analysis demonstrated that: (1) it is possible to simultaneously synthesize economic-environmental aspects into a "global" performance indicator; (2) at farm level there might be substantial hidden costs from life cycle potential environmental impacts; (3) crop cultivation with reclaimed water could result with environmental benefits of higher value than cost; (4) external costs via LCA can serve as an integrated indicator to characterize important relationships and trade-offs between the economic and life cycle environmental performance.

Uncertainty analysis was out of the scope of this study. Moreover, crop cultivation has not only economic and environmental costs but also social costs and externalities that were not considered in this study. Therefore, quantitative analyses based upon different monetization methods including social externalities and uncertainty analysis are important areas for future research. This will increase the robustness of the results and provide a more accurate simulation of social and environmental externalities and their role in the total external costs.

Author Contributions: Conceptualization, K.C.; methodology, K.C.; software, A.M.; validation, A.M. and J.B.; investigation, A.M.; data curation, K.C.; writing-original draft preparation, K.C.; writing-review and editing, K.C., A.M., and J.B. All authors have read and agreed to the published version of the manuscript.

Funding: This research received no external funding.

Institutional Review Board Statement: Not applicable.

Informed Consent Statement: Not applicable.

Data Availability Statement: Not applicable.

Acknowledgments: K.C. thanks the Department of Agricultural Economics at Universidad de Córdoba (Spain) for hosting her as a Visiting Ph.D. student. A.M. expresses gratitude to Vito Cantore (The Institute of Sciences of Food Production, ISPA-CNR) for providing necessary feedback for the analysis. A.M. acknowledges the infrastructure and support of IR2MA-Large Scale Irrigation Management Tools for Sustainable Water Management in Rural Areas and Protection of Receiving Aquatic Ecosystems, MIS Code 5003280 (https: / / www.interregir2ma.eu/, accessed on 31 July 2021).

Conflicts of Interest: The authors declare no conflict of interest.

\section{References}

1. Mancuso, G.; Lavrnić, S.; Toscano, A. Reclaimed water to face agricultural water scarcity in the mediterranean area: An overview using sustainable development goals preliminary data. In Wastewater treatment and Reuse-Present and Future Perspectives in Technological Developments and Management Issues; Elsevier: Amsterdam, The Netherlands, 2020; pp. 113-143. [CrossRef]

2. Pistocchi, A.; Aloe, A.; Dorati, C.; Alcalde Sanz, L.; Bouraoui, F.; Gawlik, B.; Grizzetti, B.; Pastori, M.; Vigiak, O. The Potential of Water Reuse for Agricultural Irrigation in the EU a Hydro-Economic Analysis; Publications Office of the European Union: Luxembourg, 2018; ISBN 9789279772108.

3. The European Parliament and the Council Regulation (EU) 2020/741, Minimum Requirements for Water Reuse; Office of the European Union: Luxembourg, 2020; Volume 177, pp. 32-55.

4. Jaramillo, M.; Restrepo, I. Wastewater reuse in agriculture: A review about its limitations and benefits. Sustainability 2017, 9, 1734. [CrossRef]

5. Arborea, S.; Giannoccaro, G.; de Gennaro, B.; Iacobellis, V.; Piccinni, A. Cost-benefit analysis of wastewater reuse in Puglia, southern Italy. Water 2017, 9, 175. [CrossRef] 
6. Azeb, L.; Hartani, T.; Aitmouheb, N.; Pradeleix, L.; Hajjaji, N.; Aribi, S. Life cycle assessment of cucumber irrigation: Unplanned water reuse versus groundwater resources in Tipaza (Algeria). J. Water Reuse Desalin. 2020, 10, 227-238. [CrossRef]

7. Romeiko, X.X. A comparative life cycle assessment of crop systems irrigated with the groundwater and reclaimed water in northern China. Sustainability 2019, 11, 2743. [CrossRef]

8. Arzate, S.; Pfister, S.; Oberschelp, C.; Sánchez-Pérez, J.A. Environmental impacts of an advanced oxidation process as tertiary treatment in a wastewater treatment plant. Sci. Total Environ. 2019, 694, 133572. [CrossRef]

9. Foglia, A.; Andreola, C.; Cipolletta, G.; Radini, S.; Akyol, Ç.; Eusebi, A.L.; Stanchev, P.; Katsou, E.; Fatone, F. Comparative life cycle environmental and economic assessment of anaerobic membrane bioreactor and disinfection for reclaimed water reuse in agricultural irrigation: A case study in Italy. J. Clean. Prod. 2021, 293, 126201. [CrossRef]

10. Canaj, K.; Morrone, D.; Roma, R.; Boari, F.; Cantore, V.; Todorovic, M. Reclaimed water for vineyard irrigation in a mediterranean context: Life cycle environmental impacts, life cycle costs, and eco-efficiency. Water 2021, 13, 2242. [CrossRef]

11. Hernández-Sancho, F.; Lamizana-Diallo, B.; Mateo-Sagasta, M.; Qadir, M. Economic Valuation of Wastewater: The Cost of Action and the Cost of No Action; United Nations Environment Programme (UNEP): Nairobi, Kenya, 2015; p. 72. ISBN 978-92-807-3474-4.

12. De Bruyn, S.; Bijleveld, M.; de Graaff, L.; Schep, E.; Schroten, A.; Vergeer, R.; Ahdour, S. Environmental Prices Handbook EU28 Version-Methods and Numbers for Valuation of Environmental Impacts; CE Delft: Delft, The Netherlands, $2018 ;$ p. 177.

13. de Groot Ruiz, A.; Fobelets, V.; Grosscurt, C.; Galgani, P.; Lord, R.; Hardwicke, R.; Tarin, M.; Gautham, P.; McNeil, D.; Aird, S. The External Costs of Banana Production: A Global Study; Fairtrade International: Bonn, Germany, 2017; p. 65.

14. Pizzol, M.; Weidema, B.; Brandão, M.; Osset, P. Monetary valuation in life cycle assessment: A review. J. Clean. Prod. 2015, 86, 170-179. [CrossRef]

15. Arendt, R.; Bachmann, T.M.; Motoshita, M.; Bach, V.; Finkbeiner, M. Comparison of different monetization methods in LCA: A review. Sustainability 2020, 12, 10493. [CrossRef]

16. Canaj, K.; Mehmeti, A.; Morrone, D.; Toma, P.; Todorović, M. Life cycle-based evaluation of environmental impacts and external costs of treated wastewater reuse for irrigation: A case study in southern Italy. J. Clean. Prod. 2021, 293, 126142. [CrossRef]

17. Morel, S.; Traverso, M.; Preiss, P. Discussion panel—assessment of externalities: Monetisation and social LCA. In Designing Sustainable Technologies, Products and Policies; Springer International Publishing: Cham, Switzerland, 2018; pp. 391-396. [CrossRef]

18. Rajabi Hamedani, S.; Kuppens, T.; Malina, R.; Bocci, E.; Colantoni, A.; Villarini, M. Life cycle assessment and environmental valuation of biochar production: Two case studies in Belgium. Energies 2019, 12, 2166. [CrossRef]

19. Olba-Zięty, E.; Stolarski, M.J.; Krzyżaniak, M.; Gołaszewski, J. Environmental external cost of poplar wood chips sustainable production. J. Clean. Prod. 2020, 252, 119854. [CrossRef]

20. Huijbregts, M.A.J.; Steinmann, Z.J.N.; Elshout, P.M.F.; Stam, G.; Verones, F.; Vieira, M.; Zijp, M.; Hollander, A.; van Zelm, R. ReCiPe2016: A harmonised life cycle impact assessment method at midpoint and endpoint level. Int. J. Life Cycle Assess. 2017, 22, 138-147. [CrossRef]

21. Al-Qahtani, A.; Parkinson, B.; Hellgardt, K.; Shah, N.; Guillen-Gosalbez, G. Uncovering the true cost of hydrogen production routes using life cycle monetisation. Appl. Energy 2021, 281, 115958. [CrossRef]

22. Greenfeld, A.; Becker, N.; Bornman, J.F.; Spatari, S.; Angel, D.L. Monetizing environmental impact of integrated aquaponic farming compared to separate systems. Sci. Total Environ. 2021, 792, 148459. [CrossRef] [PubMed]

23. Huysegoms, L.; Rousseau, S.; Cappuyns, V. Friends or foes? Monetized life cycle assessment and cost-benefit analysis of the site remediation of a former gas plant. Sci. Total Environ. 2018, 619, 258-271. [CrossRef] [PubMed]

24. Theregowda, R.B.; Vidic, R.; Landis, A.E.; Dzombak, D.A.; Matthews, H.S. Integrating external costs with life cycle costs of emissions from tertiary treatment of municipal wastewater for reuse in cooling systems. J. Clean. Prod. 2016, 112, 4733-4740. [CrossRef]

25. True Price. Available online: https://trueprice.org/true-price-resources (accessed on 28 August 2021).

26. Hernández-Sancho, F.; Molinos-Senante, M.; Sala-Garrido, R. Economic valuation of environmental benefits from wastewater treatment processes: An empirical approach for Spain. Sci. Total Environ. 2010, 408, 953-957. [CrossRef]

27. Molinos-Senante, M.; Hernández-Sancho, F.; Sala-Garrido, R. Cost-benefit analysis of water-reuse projects for environmental purposes: A case study for Spanish wastewater treatment plants. J. Environ. Manage. 2011, 92, 3091-3097. [CrossRef] [PubMed]

28. Sieverding, H.; Kebreab, E.; Johnson, J.M.F.; Xu, H.; Wang, M.; Del Grosso, S.J.; Bruggeman, S.; Stewart, C.E.; Westhoff, S.; Ristau, J.; et al. A life cycle analysis (LCA) primer for the agricultural community. Agron. J. 2020, 112, 3788-3807. [CrossRef]

29. Vergine, P.; Salerno, C.; Libutti, A.; Beneduce, L.; Gatta, G.; Berardi, G.; Pollice, A. Closing the water cycle in the agro-industrial sector by reusing treated wastewater for irrigation. J. Clean. Prod. 2017, 164, 587-596. [CrossRef]

30. Disciglio, G.; Gatta, G.; Libutti, A.; Tarantino, A.; Frabboni, L.; Tarantino, E. Use of treated municipal wastewater on artichoke crop. Int. J. Agric. Biosyst. Eng. 2014, 8, 400-406. [CrossRef]

31. Gatta, G.; Libutti, A.; Beneduce, L.; Gagliardi, A.; Disciglio, G.; Lonigro, A.; Tarantino, E. Reuse of treated municipal wastewater for globe artichoke irrigation: Assessment of effects on morpho-quantitative parameters and microbial safety of yield. Sci. Hortic. 2016, 213, 55-65. [CrossRef]

32. Ecoinvent Database Version 3.1 Swiss Centre for Life Cycle Inventories, Switzerland. Available online: https://www.ecoinvent. org/database/ecoinvent-371/ecoinvent-371.html (accessed on 1 July 2021).

33. Koeble, R. The Global Nitrous Oxide Calculator-GNOC-Online Tool Manual.; European Commission Joint Research Centre: Ispra, Italy, 2014; Volume 1.2.4, p. 40. 
34. Nemecek, T.; Kagi, T. Life cycle inventories of agricultural production systems. In Ecoinvent Report No. 15. Final Rep. Ecoinvent V2.0; Agroscope Reckenholz-Tanikon Research Station: Zürich, Switzerland, 2007; pp. 1-360. Available online: https://db. ecoinvent.org/reports/15_Agriculture.pdf (accessed on 15 June 2021).

35. Ponsioen, T.; Nuhoff-isakhanyan, G.; Vellinga, T.; Baltussen, W.; Boone, K.; Woltjer, G. Monetisation of Sustainability Impacts of Food Production and Consumption; Wageningen Economic Research: Hague, The Netherlands, 2020. [CrossRef]

36. Green Delta Open LCA Version 1.10. Green Delta GmbH: Berlin, Germany. Available online: https://www.openlca.org/ download/ (accessed on 10 July 2021).

37. Balmford, A.; Amano, T.; Bartlett, H.; Chadwick, D.; Collins, A.; Edwards, D.; Field, R.; Garnsworthy, P.; Green, R.; Smith, P.; et al. The environmental costs and benefits of high-yield farming. Nat. Sustain. 2018, 1, 477-485. [CrossRef]

38. Ntinas, G.K.; Neumair, M.; Tsadilas, C.D.; Meyer, J. Carbon footprint and cumulative energy demand of greenhouse and openfield tomato cultivation systems under southern and central European climatic conditions. J. Clean. Prod. 2017, 142, 3617-3626. [CrossRef]

39. Roselli, L.; Casieri, A.; de Gennaro, B.C.; Sardaro, R.; Russo, G. Environmental and economic sustainability of table grape production in Italy. Sustainable 2020, 12, 3670. [CrossRef]

40. Martin-Gorriz, B.; Soto-García, M.; Martínez-Alvarez, V. Energy and greenhouse-gas emissions in irrigated agriculture of SE (southeast) Spain. Effects of alternative water supply scenarios. Energy 2014, 77, 478-488. [CrossRef]

41. Moretti, M.; Van Passel, S.; Camposeo, S.; Pedrero, F.; Dogot, T.; Lebailly, P.; Vivaldi, G.A. Modelling environmental impacts of treated municipal wastewater reuse for tree crops irrigation in the Mediterranean coastal region. Sci. Total Environ. 2019, 660, 1513-1521. [CrossRef]

42. Arena, C.; Genco, M.; Mazzola, M.R. Environmental benefits and economical sustainability of urban wastewater reuse for irrigation-A cost-benefit analysis of an existing reuse project in Puglia, Italy. Water 2020, 12, 2926. [CrossRef] 